\title{
Identifying and ranking of strategies to implement green supply chain management in Indian manufacturing industry using Analytical Hierarchy Process
}

\author{
Sunil Luthra ${ }^{1}$, Dixit Garg ${ }^{2}$, Abid Haleem ${ }^{3}$ \\ ${ }^{1}$ Department of Mechanical Engineering, National Institute of Technology (India) \\ ${ }^{2}$ National Institute of Technology (India) \\ ${ }^{3} J a m i a$ Millia Islamia University (India) \\ sunillutbra1977@.gmail.com,dixitgarg@yahoo.co.in,baleem.abid@.gmail.com
}

Received: January 2013

Accepted: July 2013

\section{A bstrac:}

Purpose The study aims to identify and rank the major strategies that help achieve successful implementation of Green Supply Chain Management (GSCM) in Indian manufacturing industry.

Design/methodalogy/approadr. Strategies to implement GSCM have been identified thorough extensive literature review and then experts' opinion is sought for categorizing them into four representative dimensions which are then ranked using Analytic Hierarchy Process (AHP).

Findings: The study categorizes the GSCM implementation strategies into four dimensions Non members of supply chain, downward stream supply chain Members, Organizational members of supply chain and upward stream supply chain members. These dimensions are found to play an important role in greening the supply chains enabling the practicing firms achieve enhanced operational performances.

Researd limitations/implications: AHP is used for ranking the GSCM implementation strategies in Indian manufacturing scenario. The pair-wise comparisons are made on the basis of the 
opinion of the experts drawn from academia and industry. As is natural, opinions of experts may not always be free from bias or prejudices. Moreover, the study relied more on the GSCM practices literature in developed nations as only limited literature related to the undertaken work in the Indian context was available.

Practical implications: This paper may play important role in understanding various strategies and ranking them in order of importance. This facilitates firms prioritize different actions for achieving high GSCM performances in Indian manufacturing industry. Strategic implementation of green supply chain management will help Indian manufacturing enterprises enjoy cost and efficiency benefits.

Originality/value GSCM is a relatively new topic for majority of Indian manufacturing industries. This work is likely to help GSCM practitioners select suitable strategies in consonance with the government regulations and customers' requirements.

Keyword: Analytic Hierarchy Process (AHP), Green Supply Chain Management (GSCM), GSCM implementation strategies, Indian manufacturing industry, Supply Chain Management (SCM)

\section{Introduction}

Green Supply Chain Management (GSCM) adds 'green' component to the conventional supply chains by including practices like green operations, green design, green manufacturing, reverse logistics and waste management (Srivastava, 2007). GSCM has been gaining much attention of academia and industry over the last few years. The companies cannot afford to ignore environmental issues in today's competitive business environment. Increasing government regulations and stronger public mandates for environmental accountability have brought the green issues high on the strategic planning agenda of manufacturing firms (Walton, Handfield \& Melnyk, 1998). GSCM practices have become a very important part of company's policy and are increasingly turning into a major strategic thrust in business organizations. GSCM is a relatively new concept for the majority of Indian manufacturing firms.

Strategic planning in GSCM context means the identification of relevant goals and specification of long term plans for managing those goals (Mudgal, Shankar, Talib \& Raj, 2010). It charts out the future course of action for GSCM implementation. The biggest challenge in GSCM practices for companies is to select suitable strategies in accordance with the stipulated regulations and customers requirements ( $\mathrm{Hsu} \& \mathrm{Hu}, 2008$ ). Several studies have emphasized on developing GSCM strategies from an overall organizational perspective. Chen, Shih, Wu and Shyur (2009) provided a guideline for the electronic industry to choose an appropriate GSCM strategy, which integrates environmental perception with corporate functional strategies in order to achieve an 
effective green management. Baines, Brown, Benedettini and Ball (2012) examined the green production systems literature with a view to examine the competitive advantage gained by firms as a consequence of adoption of green strategy.

Hsu and $\mathrm{Hu}$ (2008) used fuzzy analytic hierarchy process to prioritize the relative importance of four dimensions (supplier management, product recycling, organization involvement and life cycle management) and twenty approaches to implement GSCM in electronic industry in Taiwan. The findings indicated that the organizations placing more emphasis on supplier performance management find it easy to implement GSCM successfully.

Chen, Shih, Shyur and Wu (2012) evaluated GSCM strategies for choosing business functions and activities effectively in the electronics industry of Taiwan. Shiue and Lin (2012) evaluated various recycling strategies to obtain the optimal recycling collection strategy in the upstream of the solar energy sector. Evaluation model was constructed using analytic network process technique considering four strategies and twenty indicators. Wu, Jim Wu, Chen and Goh (2013) examined the multiple relationships among supply chain strategy, corporate environmental strategy and firm performance. They suggested that the supply chain and corporate environmental strategies should be aligned to enhance firm performance.

Due to the fact that most of the companies have only just started exploring environmental concerns in the recent years, a number of environmental factors are yet to be identified systematically (Chen et al., 2009). Due to increasing regulatory, competitive and marketing pressures for environmental sustainability, the enterprises have begun to realize the need of implementing the strategies for reducing their environmental impact (Baresel-Bofinger \& Ketikidis, 2010). The role of green issues is still regarded as neutral to competitive strategy, but neutrality is pursued only against external stakeholders and not the internal greening efforts of the companies. Organizations take up green improvement initiatives because they seek to align with competitors or satisfy expectations of customers, governments, investors, interest groups, and the surrounding community. As society becomes increasingly aware and concerned about environmental issues, manufacturing companies are bound to adopt green strategies in their bid to achieve their respective goals in an efficient and economic way (Baines et al., 2012).

The Indian manufacturing industry is considered an emerging sector and has the potential to enhance further the economic development of the country. A very dismal Environmental Performance Index of India for 2012 shows that awareness of GSCM in India is poor and there is a need to spread the GSCM knowledge far and wide. Business managers need to be equipped well to identify, analyze and manage their supply chain processes and integrate environmental concerns into the processes from a more diverse range of sources and contexts. This involves identification and understanding of various element/strategies of green supply chains (Mudgal, Shankar, Talib \& Raj, 2009). Adopting internal and external sustainable 
strategies improves both economic and environmental performance (Zhu \& Sarkis, 2004). Companies are focusing more on strategy alignment, continuous process improvement and cost reduction. The success of a company depends on developing innovative supply chain strategies that help it win orders and in turn make money from information while driving continuous improvement (Kushwaha, 2012). Indian companies are also facing competitive, regulatory and community pressures to move towards greening their supply chains (Luthra, Qadri, Garg \& Haleem, 2013). Therefore, the biggest challenge in GSCM implementation is to choose suitable strategies in accordance with the regulations and customers' requirements. Strategies to implement GSCM help Indian manufacturing enterprises gain cost and efficiency benefits (Nimawat \& Namdev, 2012). This strongly supports the need for the study to identify and rank the GSCM implementation strategies in Indian manufacturing industry.

The two main objectives of this paper are:

- Identify various strategies to implement GSCM in Indian manufacturing industry

- Ranking of strategies to implement GSCM in Indian manufacturing industry

We have identified Analytic Hierarchy Process (AHP) as an appropriate methodology to rank various strategies to implement green supply chain management will help Indian manufacturing. AHP, as a decision support tool, uses a multilevel hierarchical structure of objectives, criteria, sub criteria and alternatives. It works as a multi-attribute decision making methodology which was first developed and applied by Saaty in 1977 . The AHP methodology compares criteria, or alternatives with respect to a criterion, in a natural, pair wise mode (Saaty, 1980, 1986, 1994a, 1994b). The resultant can be used to compare and rank the alternatives and, hence, assist the decision maker in making a choice (Saaty, 2000, 2008).

This paper is organized as follows. The next section covers the state-of-the-art of GSCM practice which provides the basis for identification of major GSCM implementation strategies in this study. The GSCM strategies thus identified are then categorized into four representative dimensions. The research framework and methodology is explained in the next section. The results are then presented and discussed. The concluding sections deal with the statement of the limitations of the study, some suggestions regarding direction and scope of further research on the topic.

\section{Literature review: GSCM}

Over the last few years, GSCM has attracted attention of a number of researchers and supply chain practitioners. A brief account of the work on the GSCM related issues is as follows:

Zhu and Sarkis (2004) assessed the general relationship between specific GSCM practices and performance in Chinese manufacturing enterprises. They investigated how quality management and just-in-time manufacturing principles influence the relationship between 
GSCM practices and performance. Hervani, Helms and Sarkis (2005) provided an overview of the various issues related to GSCM performance measurement. Chien and Shih (2007a, 2007b) investigated GSCM practices adopted by the electrical and electronic industry in Taiwan. They also established relationship between management practices and organization performance under European Union directives. Sarkis, Hasan and Shankar (2007) developed an interpretive structural model of environmentally conscious manufacturing barriers. Yu (2007) studied factors influencing the adoption of green supply chain practices in the logistics industry in Taiwan. Zhu, Sarkis \& Lai (2007a) explored GSCM implementation in manufacturing sector across China and studied the links between GSCM initiatives and performance outcomes. They examined the implementation levels of GSCM in four different manufacturing sectors of China. Zhu, Sarkis \& Lai (2007b) expanded on previous work and explored the GSCM pressures, drivers, initiatives and performance of the automotive supply chain using an empirical analysis in automotive enterprises within China. The results showed that the Chinese automobile supply chain enterprises had experienced high and increasing regulatory and market pressures and strong internal drivers for GSCM practice adoption were present.

Lin and Juang (2008) investigated the selection process for green suppliers in the biotechnology industry with the help of the analytic hierarchy process. They constructed a model for the evaluating upstream green suppliers for biotechnology manufacturers. Zhu, Sarkis \& Lai (2008a) evaluated GSCM practices and related them to closed loop supply chain model with manufacturers. Findings suggested that capabilities of Chinese organizations on the adoption of GSCM practices and practices were not equal across the four industrial manufacturing sectors. Zhu, Sarkis \& Lai (2008b) formulated a measurement model for assessing the degree GSCM practices implementation achieved by the manufacturers. They presented practitioners with a twenty one item measurement scale for evaluating the different facets of their GSCM practices implementation. Hsu and $\mathrm{Hu}$ (2009) used analytic network process approach to incorporate the issue of hazardous substance management into supplier selection. The criteria of hazardous substance management were categorized into four dimensions and a multi-criteria decision model was proposed. Mudgal et al. (2009) developed interpretive structural modeling (ISM) based model for greening the supply chain in Indian manufacturing industries.

$\mathrm{Hu}$ and Hsu (2010) identified critical success factors for implementing GSCM in electrical and electronic industries in Taiwan. They identified twenty critical factors and divided them into four dimensions i.e. supplier management, product recycling, organization involvement and lifecycle management. Mudgal et al. (2010) proposed an ISM based model for identifying the barriers of green supply chain Practices in Indian manufacturing industries. Shang. Lu and $\mathrm{Li}$ (2010) investigated crucial GSCM capability dimensions and firm performance in electronics goods manufacturing firms in Taiwan. Factor analysis was carried out to reduce the identified GSCM attributes into six critical GSCM factors. The six GSCM factors thus arrived at were labeled as: green manufacturing and packaging, environmental participation, green marketing, 
green supplier, green stock, and green eco-design. The results suggested that firms with a better GSCM capability attain a comparatively higher performance level.

Choudhary (2011) developed the relationships among performance measurement criteria using analytic hierarchy process. Performance criteria were based upon five factors namely, internal environment management, green purchasing, customer cooperation, investment recovery and eco-design. Diabat and Govidan (2011) suggested GSCM as an important organizational philosophy to reduce environmental risks. They provided ISM based model for enablers to implement green supply chain management practices by taking a case study. Eltayeb, Zailani and Ramayah (2011) assessed the actual environmental, economic and intangible outcomes resulting from the adoption of green supply chain initiatives. Luthra, Kumar, Kumar and Haleem (2011) developed ISM based model of barriers in GSCM implementation in Indian automobile industry. Olugu, Wong and Shaharoun (2011) identified key performance measures for an automobile green supply chain. Performance measures for the forward and reverse chains were developed. Peng (2012) utilized analytic hierarchy process and grey relational analysis techniques for optimum selection of green suppliers. He established green supplier evaluation index system.

\section{Strategies to implement GSCM in Indian manufacturing industry identification}

Literature was reviewed to identify various strategies to implement GSCM in Indian manufacturing industry. Literature survey was conducted by searching key words like GSCM strategies; GSCM Implementation; GSCM in Indian manufacturing industry; Strategies to implement GSCM. Science direct; Emerald; Scopus; DOAJ; Google search and Google scholar databases have been used. A search criterion was based on books and research papers published in journals and conference proceedings. Thirty important strategies were identified from extensive literature review. The paucity of literature in the Indian context forced us to consider the literature available for other developed/developing countries and assume somewhat similar scenario for India for identifying the relevant GSCM strategies.

We conducted a workshop, in which the experts, four from academia and five from industry, were invited for a brainstorming session to seek their opinion on how important a role the strategies play of in achieving high GSCM performances in Indian manufacturing industry. Strategies identified through extensive literature review were validated through discussions with experts (academia \& senior/middle level engineers/managers) and some thirty strategies have been categorized in four dimensions based upon their direct or indirect role in greening the supply i.e. non-members of supply chain, downward stream supply chain members, organizational perspective and upward stream supply chain members; and some sub groups like Innovative green practices implementation, Top management perspective etc. These are explained as follows: 


\subsection{Non-members of supply chain}

Non-members of supply chain (International environmental agreements, Central government legislations, State government legislations and Non government organizations) play vital role in greening the supply chain. They are explained as:

\subsubsection{International environment agreements}

International environmental agreements, such as the Kyoto agreement, the Climate Change Treaty and the Montreal Protocol (Chien \& Shih, 2007a, b) influence the manufacturing companies and the government. International organizations formulate various acts and reach agreements which directly affect the countries as well as companies (Yu, 2007; Yu \& Hui, 2008). International environment agreements may support and guide government of India to take initiatives towards GSCM implementation (Luthra et al., 2011).

\subsubsection{Central and state government legalizations}

Extant literature reveals the importance of government regulations in greening of the supply chains (Green, Morton \& New, 1996; Min \& Galle, 2001; Walton et al., 1998; Beamon, 1999; Hall, 2001; Pun, Hui, Lau, Law \& Lewis, 2002; Nagel, 2003; Zhu, Sarkis \& Geng, 2005; Walker, Sisto \& McBain, 2008; Lee, 2008; Qadri, Haleem \& Arif, 2011). The latest government policies prohibit production of goods using environmentally destructive materials and polluting processes. Different countries have different 'bodies' in the form of ministries, departments or councils for protecting and promoting green thinking in the society. In India, there are several ministries - Ministry of Environment and Forests; Ministry of Water Resources; Ministry of Earth Sciences and Ministry of Science and Technology etc. that have 'direct role' in dealing with green issues (Luthra, Kumar, Kumar \& Haleem, 2010). Under each ministry there are certain Departments/Boards /Councils, like Central Pollution Control Board under Ministry of Environment \& Forests; Department of Science and Technology under Ministry of Science and Technology, that are actively working on green issues. At the state level, there are similar 'bodies' for promoting green practices (Luthra et al., 2011).

\subsubsection{Non government organizations}

Non government organizations (NGOs) may play important role in greening the supply chain, particularly in partnerships with key stakeholders as a part of their commitment to serve individuals and community. The NGOs these days are developing a more sophisticated understanding of environmental problems based on sound scientific research and are developing effective strategies to solve environmental problems through strategic partnerships (Kong et al., 2002). 


\subsection{Downward stream supply chain members}

Downward stream supply chain members are vendors and suppliers. The manufacturers cannot produce green products unless they work together with suppliers and vendors. Therefore, downward stream supply chain members plays important role in greening the supply chains. Some of the ways to achieve the greening objective are explained as follows:

\subsubsection{Involvement of suppliers and vendors in green activities}

Company looking to transition to a green supply chain should be able to find suppliers who have minimized their environmental impact without reducing the quality of their product or raising costs significantly (Kushwaha, 2011). Strong relationships with suppliers result in lower inventory level, cost and higher accuracy (Luthra et al., 2010). The green suppliers can be the biggest assets to the organization but poor choice can make them biggest liability also (Agarwal \& Vijayvargy, 2012).

\subsubsection{Training programs}

Training and education are the prime requirements for achieving successful implementation of GSCM in any organization (Ravi \& Shankar, 2005; Sarkis et al., 2007; Scupola, 2003). Training programs for both employees and suppliers help disseminate the information and knowledge about the company's sustainability determination (Wu, Dunn \& Forman, 2012).

\subsubsection{Technology transfer to vendors/suppliers}

Technology advancement helps in developing energy efficient solutions leading to a more favorable impact on the environment (Yu \& Hui, 2008). Technology transfer to vendors/suppliers is necessary to obtain objective of environment friendly practices (Luthra et al., 2011).

\subsubsection{Environmental auditing of suppliers and vendors}

Companies should also set up a green audit management or environmental audit management system to ensure that suppliers/vendors satisfy the product requirement. This allows the supplier to gain understanding of the industry's environmental strategy, so that the supplier is able to assist the company in achieving its targeted corporate social responsibility (Wang \& Gupta, 2011).

\subsection{Organization perspective}

Organization plays very important role in greening the supply chain. Organizations may provide appropriate technologies, resources and motivation to their employee, which helps in implementing green practices (Jeyaraj, Rottman \& Lacity, 2006). Organizational perspective related to greening of supply chains covers the following issues: 


\subsubsection{Innovative green practices implementation}

Innovative green practices implementation includes Environment Management System (EMS) Implementation; Green Procurement Strategies; Green Product Development and Design Practices Adoption; Use of Environment Friendly Products and Process Optimization; Use of Environmental Friendly Packing and Labeling of the Products; Use of Environmental Friendly Transportation and Distribution. They are explained as follows:

\section{Environment management systems implementation}

Environmental Management System (EMS) ISO: 14000 Series, is a set of Standards for improving environmental management practices around the globe (Mudgal et al., 2009). Environment management programs may be planned and implemented towards effective and efficient implementation of GSCM (Srivastava, 2007). Policies that encourage facilities to adopt EMS are indirectly related to implementation of GSCM practices (Darnall, Jolley \& Handfield, 2008). EMS implementation enables organizations to achieve compliance with environmental regulations and controls environmental impact of all activities, products and services in compliance with self declared environmental policy (Shen \& Tam, 2002; Zhu \& Sarkis, 2006).

\section{Green procurement strategies}

Green procurement or purchasing adds environmental aspects to the basic criteria - price and performance, when making purchasing decisions. This practice involves the selection of supply chain partners (raw material, components and subassemblies suppliers) based on environmental standards and eco labels (Mallidis \& Vlachos, 2010). Green procurement strategies may integrate environmental criteria to the restrict use of hazardous substances on the procurement materials; components or products that they are neither recyclable nor reusable (Sarkis, 2003). Green procurement strategies may improve environmental performance of products and services (Chien \& Shih, 2007a, b). Effective and standardized purchasing management can have a significantly positive effect on business performance (Emiliani, Stec \& Grasso, 2005; SanchezRodrigues, Hemsworth \& Clavel, 2006; Quintens, Pauwels \& Matthyssens, 2006).

\section{Green product development and design practices adoption}

Green product development addresses environmental issues through product design (Hendrickson \& Tuttle., 1997; Mudgal et. al., 2009). Eco-design is a systematic way to include environmental life cycle considerations in the product design. Eco design aims at avoiding or minimizing environmental impacts of a product throughout its life cycle (Alhola, 2008) and covers the whole product chain from materials extraction, through production processes, packaging, transport and product use phase to the end-of-life treatment (NRCC, 2003). Ecodesign enables organizations to improve their environmental performance and close the supply chain loop by handling product functionality while minimizing life-cycle environmental impacts (Zhu et al., 2008a, 2008b). 
Optimization of processes reduces air emissions, noise etc. The use of cleaner technology/ processes results in a lot of savings in terms of energy, water and other utilities effecting which cost reduction ultimately (Choudhary \& Seth, 2011). Use and development of newer environment-friendly products and processes help improve the organization's overall environmental performance (Luthra et. al., 2011)

\section{Use of environmental friendly packing and labeling of the products}

Use of bio-degradable environment-friendly raw materials may be emphasized by the design department (Min \& Galle, 2001). Environmental friendly packing refers to use of recyclable or dissolvable materials for packing. Environment-friendly packing and labeling of products has a clear objective of encouraging business to market greener products (Fielding, 2001). Use of environment friendly packing and labeling is a good way to make information about environmental choices to their customers while purchasing (Mudgal et al., 2009). Eco-labeling is a voluntary scheme designed to encourage businesses to market goods and services that are environmental friendly (Mudgal et. al., 2009).

Use of environmental friendly transportation and distribution

Environment friendly transportation and distribution can be defined as the process of moving a product from its manufacturing source to its customers with low impact on the environment (Srivastava, 2007; Yu \& Hui, 2008). The standard re-useable container may be used for the transportation of products (Wu et al., 2012).

\subsubsection{Top management perspective}

Top management support is found to be one of the most important factors in firms' environmental response (Azzone \& Noci, 1998; Carter \& Jenning, 2004). Top management perspective includes initiation and commitment, proper company policies, technology advancement and information technology enablement etc. They are explained as:

\section{Initiation and commitment}

Top management of the companies should have a high environmental concern and allocate adequate financial, technological and human resources to implement the green management concept (Quazi, 1999).

\section{Proper company policies}

Companies should provide clear, consistent and frequent communication about environmental issues with their suppliers and other partners in the green supply chain. New supportive policies to promote GSCM and other corporate environmental practices are needed primarily to 
export more products and to attract more foreign investments (Yan, 2011). As raw material costs are increasing and environmental protection legislations are becoming increasingly stringent, a focus on one firm's green operational excellence is becoming the norm in organizations these days (Simpson \& Samson, 2008).

\section{Technology advancement}

Technology advancement is advancements in machinery and equipments to improve the products and services and can increase the environmental performance (Yu, 2007; Yu \& Hui, 2008). Technology incorporates the innovation into corporate culture, encouraging new ideas and processes and solutions by all the employees of the firm (Digalwar \& Metri, 2004).

\section{Information technology enablement}

Information Technology (IT) resources have been observed as one of the very important factor to introduce and implement GSCM in any organization (Ravi \& Shankar, 2005). IT enablement will help in improving communication, better allocation and optimization of resources and reduction in paper usage, which will support the organizations to adopt green practices (Ravi \& Shankar, 2005; Sarkis et al., 2007; Yu, 2007; Yu \& Hui, 2008; Luthra et. al., 2011).

\subsubsection{Employee perspective}

Employee is also key and dominating factor in an organization effort to green its supply chain. Employee perspective is explained as follow:

Quality of human resources

The organization may recruit aware, trained and skilled professional employees which may further help in implementing GSCM (Luthra et al., 2011). Soundly trained and skilled personnel are further requirement of any organization for successful implementation of green practices. Quality human resources may help to adopt new technologies easily (Yu, 2007; Yu \& Hui, 2008).

\section{Information quality and sharing}

Effective and efficient Inter-organizations/ intra-organization communication may help in sharing of innovative ideas, schedule, trainee and activities to implement GSCM (Etzion, 2007; Cooper, 1994). Better communication, coordination and strong infrastructure may help in developing healthy organizational culture for the implementation of GSCM (Christmann, 2000; Del Brio \& Junguera, 2003; Wu \& Hang, 2009).

\section{Sufficient training programs}

Training and education are the prime requirements for achieving successful implementation of GSCM in any organization (Ravi \& Shankar, 2005; Sarkis et al., 2007; Yu \& Hui, 2008). 


\subsubsection{Economic interests}

Implementation of GSCM lowers environment load, cost for suppliers, producers and cost of ownership for customers (Stevels, 2002). Further, it lowers costs due to increased efficiency (Duber-Smith, 2005). Companies implementing green innovation can compete well and export their products in world market (Mudgal et al., 2009; Luthra et al., 2011). Industries are using improved environmental performance to lower their costs by reducing waste and reducing their environmental compliance costs. Green practices also lessen the threat of civil and criminal liability for polluting by preventing pollution at the source itself (Mudgal et al., 2009).

\subsubsection{Firm's competitiveness}

Companies that are pioneer in green innovations enjoy the first mover advantage. Early initiatives allow them to develop new markets, gain competitive advantages and command a higher price for green products (Chen, Lai \& Wen, 2006). Being environmental friendly is one method to differentiate from their competitors. So, due to their commitment to environmental issues, the green firms stand out of others and enjoy better corporate images.

\subsubsection{Industrial perspective}

Industrial perspective includes waste management, reuse and recyclability within organization; lean manufacturing and proper workplace management are explained as:

\section{Waste management}

Waste management helps in managing and minimizing waste. The practices like Recycling, reuse and remanufacturing help in waste reduction or elimination (Gungor \& Gupta, 1999; Srivastava, 2007; Ilgin \& Gupta, 2010).

\section{Reuse and re-cyclability within organization}

The organization may reduce the waste and cost of the product by implementing systematic economic recycling. The organization may reuse the waste for environment protection (Hervani et al., 2005). Proper disposal of end-product may lead to environment protection (Rogers et al., 1998).

\section{Lean manufacturing}

Lean is competitive practice that reduces costs, improves environment, and improves quality and bottom line. Lean production is used for elimination of waste in each area of production (Bhetja, Babbar, Singh \& Sachdeva, 2011). Use of lean manufacturing will help in continuous improvement and elimination of waste in all forms. Lean manufacturing identified as an integrated approach to the management of a manufacturing organization that encompasses a wide variety of practices, including just-in-time, quality systems, work teams, cellular manufacturing and supplier management (Shah \& Ward, 2003). Lean manufacturing practices have great potential for reciprocal benefits to firm environmental management practices (Mudgal et al., 2009). 
Proper workplace management may help in managing resources in efficient and effective way. Proper workplace management is a basic measure of improving environmental performance in any organization. Usage of resources like water, air and energy can be significantly reduced through minimizing leaks and spills (Mudgal et al., 2009). The 5-S (Seiri, Seiton, Seiso, Seiketsu and Shitsuke) practice is a technique used to establish and maintain a quality environment in an organization and is the key to total quality environment (Charantimath, 2003).

\subsection{Upward stream supply chain members}

Upward stream members include awareness level of customers, end-of-life management and association with local recycling organizations. These are discussed as follows:

\subsubsection{Awareness level of customers}

Customer relationships are greatly influenced by green marketing policies (Toke, Gupta \& Dandekar, 2010). The environment consideration of properties of products and services must meet the customer requirement (Zhu et al., 2008 a, 2008b). In U.S.A., an estimated 75\% of consumers claim that their purchases are influenced by reputation and $80 \%$ would be willing to pay more for environment friendly products (Lamming \& Hamapson, 1996; Chien \& Shih, 2007a, b). Aware customers generally like to purchase green products which enhance the brand image and profitability of the organizations (Mudgal et al., 2009; Mudgal et al., 2010; Luthra et al., 2011).

\subsubsection{End-of-life management}

End-of-life product management means safe disposal of products after successful end of its useful life. The concept of Life-cycle analysis was introduced to measure environmental and resource related products to the production process (Srivastava, 2007). Such a measurement considers costs relevant at all the stages in a product's life cycle - right from extraction of raw materials to final disposal after its life is over.

\subsubsection{Association with local recycling organizations}

Recycling of used products is one important contribution toward sustainability (Oskamp, 1995). There are significant environmental and economic benefits associated with recycling. Association with local recycling organizations will be more cost effective than trash collection, saves energy and supplies valuable raw materials to industry.

\section{Methodology}

We have identified relevant strategies to implement GSCM in Indian manufacturing industry through extensive literature review and discussions with experts' from academia and industry. GSCM implementation strategies ranking problem in Indian manufacturing industry has been 
dealt with questionnaire based study. A structured questionnaire was framed and all the criteria were rated by the experts.

AHP technique has been employed to rank the strategies of GSCM implementation in Indian manufacturing industry. AHP framework of implementing GSCM is structured as a hierarchy which includes four levels: goal, dimensions, criteria and sub criteria for determining the priority strategy. A Research frame work of strategies to implement GSCM in Indian manufacturing industry has been shown in Figure 1 as follows:

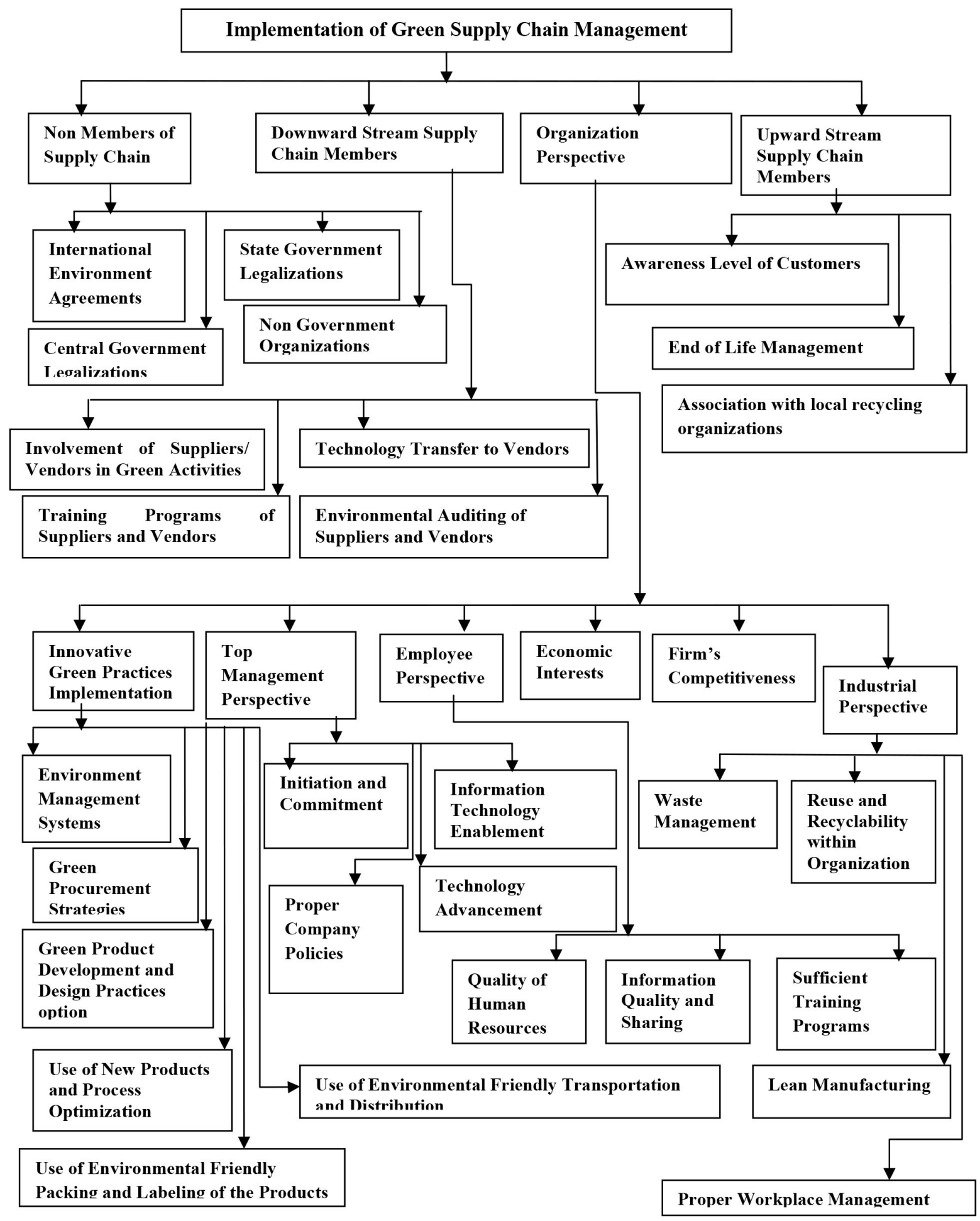

Figure 1. Research frame work of strategies to implement GSCM in Indian manufacturing industry 


\subsection{Analytical Hierarchy Process: A Brief Overview}

Analytic Hierarchy Process (AHP) developed by T.L. Saaty in 1977 as a multi attribute decision support tool, uses a multilevel hierarchical structure of objectives, criteria, sub criteria and alternatives. The methodology evaluates and ranks the alternatives with respect to various criteria in a natural, pair-wise mode (Saaty 1980, 1986, 1994a, 1994b).

The AHP methodology compares criteria, or alternatives with respect to a criterion, in a natural, pair-wise mode. To do so, it uses a fundamental scale of absolute numbers that has been proven in practice and validated by physical and decision problem experiments. The fundamental scale captures individual preferences with respect to quantitative and qualitative attributes just as well or better than other scales used for the purpose (Saaty 1980, 1986, 1994a, 1994b). It converts individual preferences into ratio scale weights that can be combined into a linear additive weight for each alternative. The resultant can be used to compare and rank the alternatives and, hence, assist the decision maker in making a choice. AHP involves the following series of steps (Saaty, 2000, 2008):

Step 1: Establishing the hierarchical structure

Construct the hierarchical structure with decision elements, decision-makers are requested to make pair-wise comparisons between decision alternatives and criteria using a nine-point scale. All matrices are developed and all pair-wises comparisons are obtained from each $\mathrm{n}$ decision-maker.

Step 2: Constructing the pair wise comparison matrix

Construct a set of pair wise comparison matrices. Each element in an upper level is used to compare the elements in the level immediately below with respect to it.

Step 3: Calculating the consistency

To ensure that the priority of elements is consistent, the maximum eigenvector or relative weights and max Eigen values are calculated. Then, compute the consistency index (CI) for each matrix order $n$ using Equation (1). Based on the CI and Random Consistency index (RI), the consistency ratio (CR) is calculated using Equation (2). The CI and CR are defined as follows (Saaty, 2000):

Compute the consistency index for each matrix of order $\mathrm{n}$ by the formulae:

$$
C I=(\lambda \max -n) /(n-1)
$$

The consistency ratio is then calculated using the formulae:

$$
\mathrm{CR}=\mathrm{CI} / \mathrm{RI}
$$


Where RI varies depending upon the order of matrix. Tables 1 shows the value of the RI for matrices of order(N) 1 to 10 obtained by approximating random indices using a sample size of 500 (Saaty, 2000).

\begin{tabular}{|c|c|c|c|c|c|c|c|c|c|c|}
\hline $\mathbf{N}$ & $\mathbf{1}$ & $\mathbf{2}$ & $\mathbf{3}$ & $\mathbf{4}$ & $\mathbf{5}$ & $\mathbf{6}$ & $\mathbf{7}$ & $\mathbf{8}$ & $\mathbf{9}$ & $\mathbf{1 0}$ \\
\hline R.I. & 0 & 0 & 0.58 & 0.90 & 1.12 & 1.24 & 1.32 & 1.41 & 1.45 & 1.49 \\
\hline
\end{tabular}

Table 1. Random index

The acceptable CR range varies according to the size of matrix i.e. 0.05 for a $3 \times 3$ matrix, 0.08 for a $4 \times 4$ matrix and 0.1 for all larger matrices, $n>=5$ (Saaty, 2000; Cheng $\&$ Li, 2001). If the value of $C R$ is equal to, or less than that value, it implies that the evaluation within the matrix is acceptable or indicates a good level of consistency in the comparative judgments represented in that matrix. In contrast, if $C R$ is more than the acceptable value, some inconsistency of judgments within that matrix has occurred and the evaluation process needs to be reviewed, reconsidered and improved. An acceptable consistency ratio helps to ensure decision-maker reliability in determining the priorities of a set of criteria (Kumar, Prashar \& Haleem, 2009).

\section{Data analysis and results}

Based on the ratings obtained through the questionnaire, matrices are formed and the priorities are synthesized using the methodology of AHP.

\subsection{Constructing the hierarchy of strategies to implement GSCM practices}

The maximum Eigen values, C.I. and pair wise comparison matrix of various strategies to implement GSCM practices has been shown in Table 2 to Table 6 as below:

The 1st level is: Implementation of Green Supply Chain Management. In 2nd level, identified four dimensions (Non members of supply chain; downward members of supply chain; organization perspective and upward members of supply Chain) have been checked for hierarchy. Table 2 shows weights given by experts to these dimensions. This problem has been solved by AHP technique.

Maximum Eigen Value $=4.14313 ;$ C.I. $=0.0477099$

Pair wise Comparison Matrix

\begin{tabular}{|c|c|c|c|c|c|}
\hline & $\begin{array}{c}\text { Non Members of } \\
\text { Supply Chain (NM) }\end{array}$ & $\begin{array}{c}\text { Downward Members } \\
\text { of Supply Chain (DM) }\end{array}$ & $\begin{array}{c}\text { Organization } \\
\text { Perspective (OP) }\end{array}$ & $\begin{array}{c}\text { Upward Members of } \\
\text { Supply Chain (UM) }\end{array}$ & $\begin{array}{c}\text { Global Priority } \\
\text { Weighting }\end{array}$ \\
\hline NM & 1 & 2 & 2 & 3 & 0.410021 \\
\hline DM & 0.5 & 1 & 2 & 2 & 0.269285 \\
\hline OP & 0.5 & 0.5 & 1 & 3 & 0.211901 \\
\hline UM & 0.333 & 0.5 & 0.333 & 1 & 0.108793 \\
\hline
\end{tabular}

Table 2. Strategies of four dimensions to implement GSCM practices 
Analytical results shown in Table 2, 'Non members of supply chain i.e. international and national regulations $(0.410021)$ '; was the most important dimension followed by 'Downward stream supply chain members i.e. suppliers and vendors (0. 269285)'; 'Organization members $(0.211901) ' ;$ and 'upward members of supply chain i.e. customers (0.108793)'. Government regulations may encourage or discourage the adoption of innovation (Scupola, 2003). Widening and intensifying green supplier producer relationships would be beneficial for the environment and contribute better management practices in eco design as well in manufacturing (Stevels, 2002).

In 3rd level decision making, dimension 1 to dimension 4 elements have been ranked using AHP technique.

\section{Dimension 1:}

Maximum Eigen Value $=4.08127 ;$ C.I. $=0.0270911$

Pair wise Comparison Matrix

\begin{tabular}{|c|c|c|c|c|c|}
\hline & $\begin{array}{c}\text { International } \\
\text { Environment } \\
\text { Agreements (IE) }\end{array}$ & $\begin{array}{c}\text { Central Government } \\
\text { Legalizations (CG) }\end{array}$ & $\begin{array}{c}\text { State Government } \\
\text { Legalizations (SG) }\end{array}$ & $\begin{array}{c}\text { Non Government } \\
\text { Organizations (NG) }\end{array}$ & Priority Weighting \\
\hline IE & 1 & 2 & 3 & 4 & 0.458558 \\
\hline CG & 0.5 & 1 & 3 & 3 & 0.304806 \\
\hline SG & 0.333 & 0.333 & 1 & 2 & 0.143218 \\
\hline NG & 0.25 & 0.333 & 0.5 & 1 & 0.093419 \\
\hline
\end{tabular}

Table 3. Strategies of Non members of supply chain (Dimension 1 )

Table 3 shows that 'International environment Agreements $(0.458558)$ ' has been found the most important strategy in dimension 1, followed by 'Central Government Legalizations (0.304806)'; 'State Government Legalizations (0.143218)' and 'Non Government Organizations (0.093419)'. Many companies and the government are also being influenced by international environmental agreements, such as the Kyoto agreement, the Climate Change Treaty and the Montreal Protocol (Chien \& Shih, 2007a, b). In this era of globalization, it has become important for the companies to comply with the regulations of the concerned countries. Domestic environmental regulations prompt companies to adopt relevant strategies and practices to enhance their environmental performance. Domestic regulations and corporate environmental missions are the two main sources of pressure (Zhu \& Sakis, 2006).

Similarly, dimension 2 to dimension 4 strategies (Table 4 to Table 6 ) has been ranked respectively. 


\section{Dimension 2:}

Maximum Eigen Value $=4.14313 ;$ C.I. $=0.0477099$

Pair wise Comparison Matrix

\begin{tabular}{|c|c|c|c|c|c|}
\hline & $\begin{array}{c}\text { Involvement of } \\
\text { Suppliers and } \\
\text { Vendors in Green } \\
\text { activities (IS) }\end{array}$ & $\begin{array}{c}\text { Training Programs } \\
\text { of Suppliers and } \\
\text { Vendors (TP) }\end{array}$ & $\begin{array}{c}\text { Technology Transfer } \\
\text { to Suppliers and } \\
\text { Vendors (TT) }\end{array}$ & $\begin{array}{c}\text { Environmental Auditing } \\
\text { of Suppliers and } \\
\text { Vendors (EA) }\end{array}$ & $\begin{array}{c}\text { Priority } \\
\text { Weighting }\end{array}$ \\
\hline IS & 1 & 0.333 & 0.333 & 0.5 & 0.10343 \\
\hline TP & 3 & 1 & 3 & 3 & 0.48835 \\
\hline TT & 3 & 0.333 & 1 & 2 & 0.25073 \\
\hline EA & 2 & 0.333 & 0.5 & 1 & 0.15749 \\
\hline
\end{tabular}

Table 4. Strategies of Downward stream supply chain members (Dimension 2)

Table 4 shows that 'Training programs of suppliers \& vendors $(0.48835)$ ' has been reported the most important strategy in dimension 2, followed by 'Technology transfer to suppliers \& vendors (0.250726)'; 'Environmental auditing of suppliers \& Vendors $(0.15749)$ ' and 'Involvement of suppliers \& vendors in green activities (0.103433)'. Regularly scheduled workshops \& seminars may help in making the employees, suppliers and contractors aware of the benefits of GSCM implementation (Rao \& Holt, 2005).

\section{Dimension 3:}

Maximum Eigen Value $=6.35975 ;$ C.I. $=0.0719509$

Pair wise Comparison Matrix

\begin{tabular}{|c|c|c|c|c|c|c|c|}
\hline & $\begin{array}{c}\text { Innovative } \\
\text { Green Practices } \\
\text { Implementation } \\
\text { (IP) }\end{array}$ & $\begin{array}{c}\text { Top } \\
\text { Management } \\
\text { Perspective } \\
(\text { TP) }\end{array}$ & $\begin{array}{c}\text { Employee } \\
\text { Perspective } \\
\text { (EP) }\end{array}$ & $\begin{array}{c}\text { Economic } \\
\text { Interests } \\
\text { (EI) }\end{array}$ & $\begin{array}{c}\text { Firm's } \\
\text { Competitiveness } \\
\text { (CP) }\end{array}$ & $\begin{array}{c}\text { Industrial } \\
\text { Perspective } \\
\text { (IP) }\end{array}$ & $\begin{array}{c}\text { Priority } \\
\text { Weighting }\end{array}$ \\
\hline IP & 5 & 1 & 5 & 3 & 2 & 2 & 0.14683 \\
\hline TP & 1 & 0.2 & 4 & 0.5 & 1 & 3 & 0.37415 \\
\hline EP & 0.25 & 0.2 & 1 & 0.25 & 0.25 & 0.5 & 0.04536 \\
\hline EI & 2 & 0.333 & 4 & 1 & 1 & 2 & 0.17709 \\
\hline CP & 1 & 0.5 & 4 & 1 & 1 & 2 & 0.16381 \\
\hline IP & 0.333 & 0.5 & 2 & 0.5 & 0.5 & 1 & 0.09276 \\
\hline
\end{tabular}

Table 5. Strategies of Organization perspective (Dimension 3)

Table 5 shows that 'Top management perspective $(0.37415)$ ' has been reported the most important strategy in dimension 3, followed by 'Economic interests (0.17709)'; 'Firm's competitiveness $(0.16381)$ '; 'Innovative green practices implementation $(0.14683)$ '; 'Industrial perspective $(0.09276)$ ' and 'Employee perspective $(0.04536)$ '. It is generally believed that commitment \& support from top management is necessary and a key driver for successful 
adoption and implementation of GSCM (Zhu et al., 2007a, b; Zhu et al. 2008a, b). Again organization strategies like innovative green practices implementation, top management perspective, employee perspective and industrial perspective are divided in to various sub criteria decision making problem ( ${ }^{\text {th }}$ Level). Their Eigen values, C.I., pair wise comparison matrix and Priority weighing are given in Table 5.1 to 5.4 respectively:

\section{Dimension 3.1. Innovative green practices implementation perspective:}

Maximum Eigen Value $=6.46542 ;$ C.I. $=0.0930849$

Pair wise Comparison Matrix

\begin{tabular}{|c|c|c|c|c|c|c|c|}
\hline & $\begin{array}{l}\text { Environment } \\
\text { Management } \\
\text { Systems } \\
\text { Implementatio } \\
\text { ns (EM) }\end{array}$ & $\begin{array}{c}\text { Green } \\
\text { Procuremen } \\
\text { t Strategies } \\
\text { (GP) }\end{array}$ & $\begin{array}{l}\text { Green Product } \\
\text { Development } \\
\text { and Design } \\
\text { Practices } \\
\text { Adoption (GD) }\end{array}$ & $\begin{array}{l}\text { Use of New } \\
\text { Products and } \\
\text { Process } \\
\text { Optimization } \\
\text { (UP) }\end{array}$ & $\begin{array}{c}\text { Use of } \\
\text { Environmental } \\
\text { Friendly } \\
\text { Packing \& } \\
\text { Labeling of the } \\
\text { Products (EP) }\end{array}$ & $\begin{array}{c}\text { Use of } \\
\text { Environmental } \\
\text { Friendly } \\
\text { Transportation } \\
\& \\
\text { Distribution(ET) }\end{array}$ & $\begin{array}{c}\text { Priority } \\
\text { Weighting }\end{array}$ \\
\hline EM & 1 & 2 & 2 & 3 & 2 & 1 & 0.257508 \\
\hline GP & 0.5 & 1 & 3 & 2 & 1 & 1 & 0.193084 \\
\hline GD & 0.5 & 0.333 & 1 & 1 & 2 & 1 & 0.132765 \\
\hline UP & 0.333 & 0.5 & 1 & 1 & 2 & 0.333 & 0.111596 \\
\hline EP & 0.5 & 1 & 0.5 & 0.5 & 1 & 1 & 0.115857 \\
\hline ET & 1 & 1 & 1 & 3 & 1 & 1 & 0.189190 \\
\hline
\end{tabular}

Table 5.1. Strategies of Innovative green practices implementation

'Environment management systems implementation $(0.257508)^{\prime}$ has been reported the most important strategy in Innovative green practices implementation strategy, followed by 'Green procurement strategies $(0.193084)^{\prime}$; 'Use of environmental friendly transportation and distribution (0.189190)'; 'Green product development and design practices adoption (0.132765)'; 'Use of environmental friendly packing and labeling of the products $(0.115857)$ ' and 'Use of new products and process optimization (0.111596)' have shown in Table 5.1. Organizations are now pressured or encouraged to implement innovative environmental management systems to meet international or local requirements (Zhu, Sarkis \& Lai, 2012a, 2012b). 


\section{Dimension 3.2. Top management perspective:}

Maximum Eigen Value $=4.19903 ;$ C.I. $=0.066343$

Pair wise Comparison Matrix

\begin{tabular}{|c|c|c|c|c|c|}
\hline & $\begin{array}{c}\text { Initiation and } \\
\text { Commitment } \\
\text { (IC) }\end{array}$ & $\begin{array}{c}\text { Proper company } \\
\text { policies (PS) }\end{array}$ & $\begin{array}{c}\text { Technology } \\
\text { Advancement (TA) }\end{array}$ & $\begin{array}{c}\text { Information } \\
\text { Technology } \\
\text { Enablement (IT) }\end{array}$ & Priority Weighting \\
\hline IC & 1 & 3 & 3 & 2 & 0.46115 \\
\hline PS & 0.333 & 1 & 2 & 3 & 0.26404 \\
\hline TA & 0.333 & 0.5 & 1 & 1 & 0.13350 \\
\hline IT & 0.5 & 0.333 & 1 & 1 & 0.14132 \\
\hline
\end{tabular}

Table 5.2. Strategies of Top management perspective

Analytical results shown in Table 5.2 demonstrate that 'Initiation and commitment $(0.46115)^{\prime}$ has been reported the most important strategy of Top management perspective strategy, followed by 'Proper company policies (0.26404)'; 'Information Technology (IT) Enablement $(0.14132)^{\prime}$ and 'Technology Advancement $(0.13350)$ ' in top management strategy. Top Management initiation Commitment is necessary for supporting GSCM ideas, practices and cooperation across organizational functions (Sarkis et. al., 2007; Zhu et. al., 2007a, 2007b).

\section{Dimension 3.3. Industrial perspective:}

Maximum Eigen Value $=4.07101 ;$ C.I. $=0.0236709$

Pair wise Comparison Matrix

\begin{tabular}{|c|c|c|c|c|c|}
\hline & $\begin{array}{c}\text { Waste } \\
\text { Management } \\
\text { (WM) }\end{array}$ & $\begin{array}{c}\text { Reuse and } \\
\text { Recyclability within } \\
\text { Organization (RO) }\end{array}$ & $\begin{array}{c}\text { Lean Manufacturing } \\
\text { (LM) }\end{array}$ & $\begin{array}{c}\text { Proper Workplace } \\
\text { Management } \\
\text { (PW) }\end{array}$ & $\begin{array}{c}\text { Priority } \\
\text { Weighting }\end{array}$ \\
\hline WM & 1 & 2 & 1 & 3 & 0.35064 \\
\hline RO & 0.5 & 1 & 1 & 3 & 0.24692 \\
\hline LM & 1 & 1 & 1 & 4 & 0.31216 \\
\hline PW & 0.333 & 0.333 & 0.25 & 1 & 0.09028 \\
\hline
\end{tabular}

Table 5.3. Strategies of Industrial perspective

'Waste management $(0.35064)$ ' was the most important strategy of Industrial perspective strategy, followed by 'Lean manufacturing (0.31216)'; 'Reuse and recyclability within organization $(0.24692)$ ' and 'Proper workplace management $(0.09028)$ ' shown in Table 5.3. Waste management is a popular topic in the literature because of the increased awareness of enterprises in the European Union, in both the EU countries and the countries which export to the EU (Zhu et al., 2007b). 


\section{Dimension 3.4. Employee perspective:}

Maximum Eigen Value $=3.05362 ;$ C.I. $=0.0268108$

Pair wise Comparison Matrix

\begin{tabular}{|c|c|c|c|c|}
\hline & $\begin{array}{c}\text { Quality of Human } \\
\text { Resources (QH) }\end{array}$ & $\begin{array}{c}\text { Information Quality and } \\
\text { Sharing (IQ) }\end{array}$ & $\begin{array}{c}\text { Sufficient Training } \\
\text { Programs (ST) }\end{array}$ & Priority Weighting \\
\hline QH & 1 & 3 & 1 & 0.39612 \\
\hline IQ & 0.333 & 1 & 0.166 & 0.10480 \\
\hline ST & 1 & 6 & 1 & 0.49908 \\
\hline
\end{tabular}

Table 5.4. Strategies of Employee perspective

Analytical results in Table 5.4 reveal that 'Sufficient training programs of employees $(0.49908)^{\prime}$ was the most important strategy of employee perspective, followed by 'Human resources quality $(0.39612)$ ' and 'Information quality and sharing $(0.10480)$ '. By training employees in pollution prevention, organizations are able to take advantage of the improved environmental performance (Luthra et al., 2013).

\section{Dimension 4:}

Maximum Eigen Value $=3.0092 ;$ C.I. $=0.00460136$

Pair wise Comparison Matrix

\begin{tabular}{|c|c|c|c|c|}
\hline & $\begin{array}{c}\text { Awareness Level of } \\
\text { Customers (AC) }\end{array}$ & $\begin{array}{c}\text { End of Life Management } \\
\text { (EL) }\end{array}$ & $\begin{array}{c}\text { Association with local recycling } \\
\text { organizations (AR) }\end{array}$ & $\begin{array}{c}\text { Priority } \\
\text { Weighting }\end{array}$ \\
\hline AC & 1 & 1 & 3 & 0.41606 \\
\hline EL & 1 & 1 & 4 & 0.45793 \\
\hline AR & 0.333 & 0.25 & 1 & 0.12601 \\
\hline
\end{tabular}

Table 6. Strategies of Upward stream supply chain members (Dimension 4)

End of life management $(0.45793)$ ' was the most important strategy, followed by 'Awareness level of customers $(0.41606)^{\prime}$ and 'Association with local recycling organizations (0.12601)' reported in Table 6. In today's scenario, product end life management has been a major issue towards greening the supply chain (Luthra et al., 2011). Consistency ratio (C.R.) values are well in acceptable range for matrices shown in Table 3 to Table 6, which ensures decisionmaker reliability (Saaty, 2000; Kumar et al., 2009).

The complete priority weighting and ranking of strategies to implement GSCM in Indian manufacturing industry is given in Table 7.

Non-members of supply chain have received the highest global weighting and upward stream supply chain members' lowest global weighting in Table 7 . They are ranked $1^{\text {st }}$ and $4^{\text {th }}$ respectively. Downward stream supply chain members and Organization members of supply 
chain are ranked $2^{\text {nd }}$ and $3^{\text {rd }}$ respectively. Further, various strategies in each dimension are also ranked. International environment agreements reported highest ranking and Non government organizations has the lowest ranking in dimension 1 (Non members of supply chain). Similarly, Training programs of suppliers \& vendors has been found to be the most important strategy and Involvement of suppliers \& vendors in green activities, the least important strategy in dimension 2 (Downward stream supply chain members). In dimension 3 (Organization perspective), Top management perspective has obtained highest rank and Employee perspective, the lowest. Similarly, in dimension 4 (Upward stream members of supply chain) End-of-life management is reported to be the most important strategy and Association with local recycling organizations emerges as the least important strategy.

Further, ranking of various strategies in organization perspective strategy like innovative green practices implementation strategy, top management perspective strategy, employee perspective strategy and industrial perspective strategy are divided into various sub-criteria decision making problem. In Innovative green practices implementation, Environment management systems implementation has been reported as the most important strategy and Use of new products and process optimization as the least important one. Likewise, in Top management perspective strategy, Top management initiation and commitment stands as the most important strategy and Technology advancement is reported as the least important strategy. Similarly, Waste management has been found the most important strategy and Proper workplace management has been is found to be the least important strategy in industrial perspective; and in Employee perspective, Sufficient training programs of employees gets the highest while Information quality and sharing has found to be the least important strategy.

Non members of supply chain namely international environment agreements, central government legislations, state government legislations and non government organizations play a key role in greening the supply chain. Regulatory bodies formulate strong regulations/legalizations for discouraging production of goods made from environmentally destructive materials and polluting processes. The pressure from Government and NGOS can enforce/support the implementation of GSCM practices in Indian manufacturing industry. Similarly, downward stream supply chain members (suppliers and vendors) and organizations involvement in green activities will help in motivating GSCM practices. Upward members of supply chain (customers) will motivate green practices by purchasing green products. The way concern about the environmental issues is increasing in the society, the companies with more adventurous green strategies are likely to rule the roost (Baines, et al., 2012). 


\begin{tabular}{|c|c|c|c|c|c|c|c|c|}
\hline S.N & Dimension & $\begin{array}{c}\text { Global } \\
\text { Priority } \\
\text { Weighting }\end{array}$ & Rank & S.N. & \multicolumn{2}{|c|}{$\begin{array}{l}\text { Strategies to implement GSCM in Indian } \\
\text { manufacturing industry }\end{array}$} & $\begin{array}{c}\text { Priority } \\
\text { Weighting }\end{array}$ & Ranking \\
\hline \multirow{4}{*}{1.} & \multirow{4}{*}{$\begin{array}{l}\text { Non Members } \\
\text { of Supply } \\
\text { Chain } \\
\text { Perspective } \\
\text { (NM) }\end{array}$} & \multirow{4}{*}{0.410021} & \multirow{4}{*}{ 1st } & 1.1 & \multicolumn{2}{|c|}{ International Environment Agreements (IE) } & 0.458558 & $1^{\text {st }}$ \\
\hline & & & & 1.2 & \multicolumn{2}{|c|}{ Central Government Legalizations (CG) } & 0.304806 & $2^{\text {nd }}$ \\
\hline & & & & 1.3 & \multicolumn{2}{|r|}{ State Government Legalizations (SG) } & 0.143218 & $3^{\text {rd }}$ \\
\hline & & & & 1.4 & \multicolumn{2}{|r|}{ Non Government Organizations (NG) } & 0.0934192 & $4^{\text {th }}$ \\
\hline \multirow{4}{*}{2.} & \multirow{4}{*}{$\begin{array}{c}\text { Downward } \\
\text { Stream Supply } \\
\text { Chain Members } \\
\text { Perspective } \\
\text { (DM) }\end{array}$} & \multirow{4}{*}{0.269285} & \multirow{4}{*}{ 2nd } & 2.1 & \multicolumn{2}{|c|}{$\begin{array}{c}\text { Involvement of Suppliers and Vendors in } \\
\text { Green activities(IS) }\end{array}$} & 0.103433 & $4^{\text {th }}$ \\
\hline & & & & 2.2 & \multicolumn{2}{|r|}{ Training Programs (TP) } & 0.48835 & $1^{\text {st }}$ \\
\hline & & & & 2.3 & \multicolumn{2}{|r|}{ Technology Transfer to Vendors (TT) } & 0.250726 & $2^{\text {nd }}$ \\
\hline & & & & 2.4 & \multicolumn{2}{|c|}{$\begin{array}{c}\text { Environmental Auditing of Suppliers and } \\
\text { Vendors (EA) }\end{array}$} & 0.15749 & $3^{\text {rd }}$ \\
\hline \multirow{23}{*}{3.} & \multirow{23}{*}{$\begin{array}{l}\text { Organization } \\
\text { Perspective } \\
\text { (OP) }\end{array}$} & \multirow{23}{*}{0.211901} & \multirow{23}{*}{$3 r d$} & \multirow{7}{*}{3.1} & \multicolumn{2}{|c|}{$\begin{array}{l}\text { Innovative Green Practices Implementation } \\
\text { (IP) }\end{array}$} & 0.14683 & $4^{\text {th }}$ \\
\hline & & & & & 3.1 .1 & $\begin{array}{c}\text { Environment Management Systems } \\
\text { Implementation (EM) }\end{array}$ & 0.257508 & $1^{s t}$ \\
\hline & & & & & 3.1 .2 & Green Procurement Strategies (GP) & 0.193084 & $2^{\text {nd }}$ \\
\hline & & & & & 3.1 .3 & $\begin{array}{l}\text { Green Product Development and } \\
\text { Design Practices Adoption (GD) }\end{array}$ & 0.132765 & $4^{\text {th }}$ \\
\hline & & & & & 3.1 .4 & $\begin{array}{c}\text { Use of New Products and Process } \\
\text { Optimization (UP) }\end{array}$ & 0.111596 & $6^{\text {th }}$ \\
\hline & & & & & 3.1 .5 & $\begin{array}{c}\text { Use of Environmental Friendly } \\
\text { Packing and Labeling of the Products } \\
\text { (EP) }\end{array}$ & 0.115857 & $5^{\text {th }}$ \\
\hline & & & & & 3.1 .6 & $\begin{array}{l}\text { Use of Environmental Friendly } \\
\text { Transportation and Distribution (ET) }\end{array}$ & 0.18919 & $3^{r d}$ \\
\hline & & & & \multirow{5}{*}{3.2} & \multicolumn{2}{|r|}{ Top Management Perspective (TP) } & 0.37415 & $1^{\text {st }}$ \\
\hline & & & & & 3.2 .1 & Initiation and Commitment (IC) & 0.46115 & $1^{\text {st }}$ \\
\hline & & & & & 3.2 .2 & Proper company policies (PS) & 0.26404 & $2^{\text {nd }}$ \\
\hline & & & & & 3.2 .3 & Technology Advancement (TA) & 0.13350 & $4^{\text {th }}$ \\
\hline & & & & & 3.2 .4 & $\begin{array}{c}\text { Information Technology (IT) } \\
\text { Enablement }\end{array}$ & 0.14132 & $3^{\text {rd }}$ \\
\hline & & & & \multirow{4}{*}{3.3} & \multicolumn{2}{|r|}{ Employee Perspective (EP) } & 0.04536 & $6^{\text {th }}$ \\
\hline & & & & & 3.3 .1 & Human Resources Quality (QH) & 0.39612 & $2^{\text {nd }}$ \\
\hline & & & & & 3.3 .2 & Information Quality and Sharing (IQ) & 0.1048 & $3^{\text {rd }}$ \\
\hline & & & & & 3.3 .3 & Sufficient Training Programs (ST) & 0.49908 & $1^{s t}$ \\
\hline & & & & 3.4 & & Economic Interests (EI) & 0.17709 & $2^{\text {nd }}$ \\
\hline & & & & 3.5 & & Firm's Competitiveness (CP) & 0.16381 & $3^{\text {rd }}$ \\
\hline & & & & & & Industrial Perspective (IP) & 0.09276 & $5^{\text {th }}$ \\
\hline & & & & & 3.6 .1 & Waste Management (WM) & 0.35064 & $1^{\text {st }}$ \\
\hline & & & & 3.6 & 3.6 .2 & $\begin{array}{c}\text { Reuse and Recyclability within } \\
\text { Organization (RO) }\end{array}$ & 0.24692 & $3^{\text {rd }}$ \\
\hline & & & & & 3.6 .3 & Lean Manufacturing (LM) & 0.31216 & $2^{\text {nd }}$ \\
\hline & & & & & 3.6 .4 & Proper Workplace Management (PW) & 0.09028 & $4^{\text {th }}$ \\
\hline & Upward Stream & & & 4.1 & & areness Level of Customers (AC) & 0.41606 & $2^{\text {nd }}$ \\
\hline 4. & $\begin{array}{l}\text { Supply Chain } \\
\text { Members }\end{array}$ & 0.108793 & 4th & 4.2 & & End of Life Management (EL) & 0.45793 & $1^{\text {st }}$ \\
\hline & $\begin{array}{c}\text { Perspective } \\
\text { (UM) }\end{array}$ & & & 4.3 & Associa & $\begin{array}{l}\text { tion with local recycling organizations } \\
\text { (AR) }\end{array}$ & 0.12601 & $3^{\text {rd }}$ \\
\hline
\end{tabular}

Table 7. The priority weighting and ranking of strategy to implement GSCM

in Indian manufacturing industry 


\section{Discussion and concluding remarks}

In this paper, an extensive literature review was carried out to identify various strategies that help in implementation of GSCM practices in Indian manufacturing industry. Thirty such strategies thus identified were, after a long brainstorming session, categorized into four strategic dimensions based on their direct or indirect role in greening. The dimensions are: non-members of supply chain, downward stream supply chain members, organization perspective and upward stream supply chain members. Some sub-groups like Innovative green practices implementation, top management perspective, industrial perspective, employee perspective etc. were also identified.

This paper may play important role to understanding various strategies and their role in greening pursuits of a company. The proposed framework permits managers to improve their understanding of GSCM practices and enables decision-makers to assess the perception of various stakeholders towards GSCM in their organization. This paper may help GSCM practitioners to select suitable strategies to strike a better fit with the environmental regulations and customers requirements. Proper selection of strategies to implement GSCM will enable the organizations to enjoy cost benefits as well as better brand image.

AHP has been used for ranking the GSCM implementation strategies. All pair-wise comparisons made in the AHP are based on the experts' opinions (selected from academia and industry). As is natural, opinion of experts may be biased or prejudiced. This may be considered as one of the limitations of this study. Moreover, the categorization of the strategies is not the final verdict on the subject and many other relevant strategies can be identified and categorized alternately depending upon the objective and perspective of future studies. As a future direction for research, Analytical Network Process (ANP) technique may also be used to determine ranking of the strategy dimensions identified in this study. The use of Interpretive Ranking Process (IRP) may also be considered for the purpose of ranking these strategies with respect to performance measures of GSCM implementation.

\section{Acknowledgements}

The authors are very much thankful to the anonymous reviewers of the paper for their constructive and helpful comments that improved the quality of the paper.

\section{References}

Agarwal, G., \& Vijayvargy, L. (2012). Green Supplier Assessment in Environmentally Responsive Supply Chains through Analytical Network Process. Proceedings of International Multi Conference of Engineers and Computer Scientists, Hong Kong, 14-16 March, 2012, 2, 16. ISSN: 2078-0966. 
Alhola, K.P. (2008). Promoting environmentally sound furniture by green public procurement. Ecological Economics, 68, 472-485. http://dx.doi.org/10.1016/j.ecolecon.2008.05.004

Azzone, G., \& Noci, G. (1998). Identifying effective PMSs for the deployment of green manufacturing strategies. International Journal of Operations \& Production Management, 18(4), 308-335. http://dx.doi.org/10.1108/01443579810199711

Baines, T., Brown, S., Benedettini, O., \& Ball, P. (2012). Examining green production and its role within the competitive strategy of manufacturers. Journal of Industrial Engineering and Management, 5(1), 53-87. http://dx.doi.org/10.3926/jiem.405

Baresel-Bofinger, A., \& Ketikidis, P. (2010). Using 'green knowledge' for implementing environmental supply chain management practices in Greek manufacturers. In 5th International Forum on Knowledge Asset Dynamics (IFKAD 2010), pp. 24-25.

Beamon, B.M. (1999). Designing the green supply chain. Logistics Information Management, 12 (4), 332-342. http://dx.doi.org/10.1108/09576059910284159

Bhetja, A.K., Babbar, R., Singh, S. \& Sachdeva, A. (2011). Study of green supply chain management in the Indian manufacturing industries: A literature review cum an analytical approach for the measurement of performance. International Journal of Computational Engineering \& Management, 13, 84-99. ISSN: 2230-7893

Carter, C.R., \& Jennings, M.M. (2004). The role of purchasing in corporate social responsibility: a structural equation analysis. Journal of Business Logistics, 25(1), 145-186. http://dx.doi.org/10.1002/j.2158-1592.2004.tb00173.x

Charantimath, P.M. (2003). Total quality management. Delhi: Pearson Education.

Chen, C.C., Shih, S.H., Shyur, H.J., \& Wu, K.S. (2012). A business strategy selection of green supply chain management via an analytic network process. Computers \& Mathematics with Applications, 64(8), 2544-2557. http://dx.doi.org/10.1016/j.camwa.2012.06.013

Chen, C.C., Shih, H.S., Wu, K.S. \& Shyur, H.J. (2009). Using ANP for the selection of green supply chain management strategies. In Proceedings of the Tenth International Symposium on the Analytic Hierarchy/Network Process, 1-15.

Chen, Y.S., Lai, S.B., \& Wen, C.T. (2006). The influence of green innovation performance on corporate advantage in Taiwan. Journal of Business Ethics, 67(4), 331-339. http://dx.doi.org/10.1007/s10551-006-9025-5

Cheng, E.W.L., \& Li, H. (2001). Information priority-setting for better resource allocation using Analytic Hierarchy Process (AHP). Information Management and Computer Security, 2, 61-70. 
Chien, M.K., \& Shih, L.H. (2007a). An empirical study of the implementation of green supply chain management practices in the electrical and electronics industries and their relation to organizational behavior. International Journal of Science and Technology, 4(3), 383-394. ISSN: $1735-1472$

Chien, M.K., \& Shih, L.H. (2007b). Relationship between management practice and organization performance under European Union directives such as ROHS, a case study on the electrical and electronics industry in Taiwan. African Journal of Environmental Science and Technology, 1(3), 37-48.

Choudhary, M., \& Seth, N. (2011). Integration of green practices in supply chain environmentThe practices of inbound, operational, outbound and reverse logistics. International Journal of Engineering Science and Technology, 3(6), 4995-4993. ISSN: 0975-5462

Choudhary, M. (2011). Inter-organizational comparison of green supply chain management using analytical hierarchy process. International Journal of Engineering Research and Industrial Applications, 4(3), 345-368. ISSN 0974-1518

Christmann, P. (2000). Effects of best practices of environmental management on cost advantage: The role of complementary assets. Academy of Management Journal, 43(4), 663-680. http://dx.doi.org/10.2307/1556360

Cooper, J. (1994). Green Logistics, European Logistics Market and Strategy. Oxford: Blackwell Business.

Darnall, N., Jolley, G.J., \& Handfield, R. (2008). Environmental management systems and green supply chain management: complements for sustainability? Journal of Business Strategy and the Environment, 1(8), 30-45. http://dx.doi.org/10.1002/bse.557

Del Brio, J.A., \& Junquera B. (2003). A review of the literature on environmental innovation management in SMEs: Implications for public policies. Technovation, 23(12), 939-948. http://dx.doi.org/10.1016/S0166-4972(02)00036-6

Diabat, A., \& Govindan, K. (2011). An analysis of the drivers affecting the implementation of green supply chain management. Resources Conservation and Recycling, 55(6), 659-667. http://dx.doi.org/10.1016/j.resconrec.2010.12.002

Digalwar, A.K., \& Metri, B.A. (2004). Performance measurement framework for world class manufacturing. International Journal of Applied Management and Technology, 3(2), 83-101.

Duber-Smith, D.C. (2005). The green imperative. Soap, Perfumery and Cosmetics, 78(8), 24-26. 
Eltayeb, T.K., Zailani, S., \& Ramayah, T. (2011). Green supply chain initiatives among certified companies in Malaysia and environmental sustainability: Investigating the outcomes. Resources, Conservation and Recycling, 495-506. http://dx.doi.org/10.1016/j.resconrec.2010.09.003

Emiliani, M.L., Stec, D.J., \& Grasso, L.P. (2005). Unintended responses to a traditional purchasing performance metric. Supply Chain Management, 10(3/4), 150-156. http://dx.doi.org/10.1108/13598540510606197

Etzion, D. (2007). Research on Organization and the Natural Environment, (1992) - Present: A Review. Journal of Management, 33(4), 637-664. http://dx.doi.org/10.1177/0149206307302553

Fielding, S. (2001). ISO 14001: A plan for environmental excellence. Industrial Maintenance \& Plant Operation, 62(8), 11-15.

Green, K., Morton, B., \& New, S. (1996). Purchasing and environmental management: interactions, policies and opportunities. Business Strategy and the Environment, 5(1), 188-197. http://dx.doi.org/10.1002/(SICI)1099-0836(199609)5:3<188::AID-BSE60>3.0.CO;2-P

Gungor, A., \& Gupta, S.M. (1999). Issues in environmentally conscious manufacturing and product recovery: A survey. Computers \& Industrial Engineering, 36, 811-853. http://dx.doi.org/10.1016/S0360-8352(99)00167-9

Hall, J. (2001). Environmental supply chain innovation. Greener Management International, 35, 105-119.

Hendrickson, L.U., \& Tuttle, D.B. (1997). Dynamic management of the environmental enterprise: A qualitative analysis. Journal of Organizational Change Management, 10(4), 363-382. http://dx.doi.org/10.1108/09534819710175875

Hervani, A.A., Helms, M.M., \& Sarkis, J. (2005). Performance measurement for green supply chain management. Benchmarking: An International Journal, 12 (4), 330-353. http://dx.doi.org/10.1108/14635770510609015

Hsu, C.W., \& Hu, A.H. (2008). Green supply chain management in the electronic industry. International Journal of Science and Technology, 5(2), 205-216. http://dx.doi.org/10.1007/BF03326014

Hsu, C.W., \& Hu, A.H. (2009). Applying hazardous substance management to supplier selection using analytic network process. Journal of Cleaner Production, 17, 255-264. http://dx.doi.org/10.1016/j.jclepro.2008.05.004

Hu, A.H., \& Hsu, C.W. (2010). Critical factors for implementing green supply chain management practice-An empirical study of electrical and electronics industries in Taiwan. Management Research Review, 33(6), 586-608. http://dx.doi.org/10.1108/01409171011050208 
Ilgin, M.A., \& Gupta, S.M. (2010). Environmentally conscious manufacturing and product recovery: A review of the state of the art. Journal of Environmental Management, 91(3), 563-591. http://dx.doi.org/10.1016/j.jenvman.2009.09.037

Jeyaraj, A., Rottman, J.W., \& Lacity, M.C. (2006). A Review of the predictors, linkages, and biases in IT innovation adoption research. Journal of Information Technology, 21(1), 1-23. http://dx.doi.org/10.1057/palgrave.jit.2000056

Kong N., Salzmann, O., Steger, U., \& Somers, A.I. (2002). Moving business/industry towards sustainable consumption: the Role of NGOs. European Management Journal, 20 (2), 109-127. http://dx.doi.org/10.1016/S0263-2373(02)00022-1

Kumar, S., Prashar N., \& Haleem A. (2009). Analytical hierarchy process applied to vendor selection problem: small Scale, medium scale and large Scale Industries. Business Intelligence Journal, August, 355-362. ISSN: 1918-2325

Kushwaha, G.S. (2011). Sustainable development through strategic green supply chain management. International Journal of Engineering and Management Sciences, 1(1), 7-11. ISSN 2229-600X

Kushwaha, G.S. (2012). Operational performance through supply chain management practices. International Journal of Business and Social Science, 3(2), 222-232.

Lamming, R., \& Hamapson, J. (1996). The environmental as a supply chain management issue. British Journal of Management, 7 (March Special Issue), 45-62.

Lee, S. (2008). Drivers for the participation of small and medium-sized suppliers in green supply chain initiatives. Supply Chain Management: an International Journal, 13(3), 185-198. http://dx.doi.org/10.1108/13598540810871235

Lin, S.S., \& Juang, Y.S. (2008). Selecting green suppliers with analytic hierarchy process for biotechnology industry. Operations and Supply Chain Management, 1(2), 115-129. ISSN:1979-3561.

Luthra, S., Kumar, V., Kumar, S., \& Haleem, A. (2010). Green supply chain management issues: A literature review approach. Journal of Information, Knowledge and Research in Mechanical Engineering, 1(1), 12-20. ISSN: 0975-668X.

Luthra, S., Kumar, V., Kumar, S., \& Haleem, A. (2011). Barriers to implement green supply chain management in automobile industry using interpretive structural modeling techniqueAn Indian perspective. Journal of Industrial Engineering and Management, 4(2), 231-257. http://dx.doi.org/10.3926/jiem.2011.v4n2.p231-257 
Luthra, S., Qadri, M.A., Garg, D., \& Haleem, A. (2013). Identification of critical success factors to achieve high green supply chain management performances in Indian automobile industry. International Journal of Logistics Systems and Management (In Press).

Mallidis, I., \& Vlachos, D. (2010). A Framework for green supply chain management. $1^{\text {st }}$ Olympus International Conference on Supply Chain, 1-2 October, 2010 Katerini, Greece, 1-16.

Min, H., \& Galle, W.P. (2001). Green purchasing practices of US firms. International Journal of Operations \& Production Management, 21(9), 1222-1238. http://dx.doi.org/10.1108/EUm0000000005923

Mudgal, R.K., Shankar, R., Talib, P., \& Raj, T. (2009). Greening the supply chain practices: An Indian perspective of enabler's relationship. International Journal of Advanced Operations Management, 1(2-3), 151-176. http://dx.doi.org/10.1504/IJAOM.2009.030671

Mudgal, R.K., Shankar, R., Talib, P., \& Raj, T. (2010). Modeling the barriers of green supply chain practices: An Indian perspective. International Journal of Logistics Systems and Management, 7(1), 81-107.

Nagel, M.H. (2003). Managing the environmental performance of production facilities in the electronics industry: more than application of the concept of cleaner production. Journal of Cleaner Production, 11, 11-26. http://dx.doi.org/10.1016/S0959-6526(02)00021-5

National Research Council Canada (NRCC 2003). DfE and the Product Life Cycle. http://dfesce.nrc-cnrc.gc.ca/overview/lifeCycle e.html, 20.1.2003. Accessed on 12 March 2012

Nimawat, D., \& Namdev, V. (2012). An overview of green supply chain management in India. Research Journal of Recent Sciences, 1(6), 77-82. Available at: http://www.joics.com

Olugu, E.U., Wong, K.Y., \& Shaharoun, A.M. (2011). Development of key performance measures for the automobile green supply chain. Resources, Conservation and Recycling, 55(6), 567-579. http://dx.doi.org/10.1016/j.resconrec.2010.06.003

Oskamp, S. (1995). Resource conservation and recycling: Behavior and policy. Journal of Social Issues, 51(4), 157-177. http://dx.doi.org/10.1111/j.1540-4560.1995.tb01353.x

Peng, J. (2012). Research on the optimization of green suppliers based on AHP and GRA. Journal of Information \& Computational Science, 9(1), 173-182.

Pun, K.F., Hui, I.K., Lau, H.C.W., Law, H.W., \& Lewis, W.G. (2002). Development of an EMS planning framework for environmental management practice. International Journal of Quality \& Reliability Management, 19(6), 688-709. http://dx.doi.org/10.1108/02656710210429573 
Qadri, M.A., Haleem, A., \& Arif, M. (2011). Identification of drivers for greening of supply chain in India. IJCPM, 3(3), 1-17. ISSN 1944-1436

Quazi, A.H. (1999). Implementation of an environmental management system: The experience of companies operating in Singapore. Industrial Management and Data Systems, 99(7), 302-311. http://dx.doi.org/10.1108/02635579910262526

Quintens, L., Pauwels, P., \& Matthyssens, P. (2006). Global purchasing strategy: Conceptualization and measurement. Industrial Marketing Management, 35(7), 881-891. http://dx.doi.org/10.1016/j.indmarman.2006.05.009

Rao, P., \& Holt, D. (2005). Do green supply chains lead to competitiveness and economic performance? International Journal of Operations and Production Management, 25(9), 898-916. http://dx.doi.org/10.1108/01443570510613956

Ravi, V., \& Shankar, R. (2005). Analysis of interactions among the barriers of reverse logistics. International Journal of Technological Forecasting and Social change, 72(8), 1011-1029. http://dx.doi.org/10.1016/j.techfore.2004.07.002

Rogers, D.S., \& Tibben-Lembke, R.S. (1998). Tibben- lembke, going backwards: Reverse Logistics trends and practices. Reverse Logistics Executive Council, Pittsburgh, PA, 1-283.

Saaty, T.L. (1980). The Analytic Hierarchy Process. New York: McGraw-Hill Book Co.

Saaty, T.L. (1986). Axiomatic Foundation of the Analytic Hierarchy Process. Management Science, 32, 841-855. http://dx.doi.org/10.1287/mnsc.32.7.841

Saaty, T.L. (1994a). Fundamentals of decision making. Pittsburgh, PA: RWS Publications.

Saaty, T.L. (1994b). How to make a decision: The analytic hierarchy process. Interfaces, 24, 19-43. http://dx.doi.org/10.1287/inte.24.6.19

Saaty, T.L. (2000). Fundamentals of decision making and priority theory. 2nd ed. Pittsburgh, PA: RWS Publications.

Saaty, T.L. (2008). Decision making with analytic hierarchy process. International Journal of Services Sciences, 1(1), 83-98. http://dx.doi.org/10.1504/IJSSCI.2008.017590

Sanchez-Rodrigues, C., Hemsworth, D., \& Clavel, J.G. (2006). An empirical study on the impact of standardization of materials and purchasing procedures on purchasing and business performance. Supply Chain Management, 11(1), 56-64. http://dx.doi.org/10.1108/13598540610642475

Sarkis, J. (2003). A strategic decision framework for green supply chain management. Journal of Cleaner Production, 11, 397-409. http://dx.doi.org/10.1016/S0959-6526(02)00062-8 
Sarkis, J., Hasan, M.A., \& Shankar, R. (2007). Evaluating environmentally conscious manufacturing barriers with Interpretive Structural Modeling. Electronic copy of this paper is available at: http://ssrn.com/abstract=956954, 24 pages.

Scupola, A. (2003). The adoption of internet commerce by SMEs in the South of Italy: An environmental, technological and organizational perspective. Journal of Global Information Technology Management, 6(1), 52-71.

Shah, R., \& Ward, P. (2003). Lean manufacturing: context, practice bundles and performance. Journal of Operations Management, 21(2), 129-149. http://dx.doi.org/10.1016/S0272-6963(02)00108-0

Shang, K.C., Lu, C.S., \& Li S. (2010). Taxonomy of green supply chain management capability among electronics-related manufacturing firms in Taiwan. Journal of Environmental Management, 91, 1218-1226. http://dx.doi.org/10.1016/j.jenvman.2010.01.016

Shen, L.Y., \& Tam, V. (2002). Implementation of environmental management in the Hong Kong construction industry. International Journal of Project Management, 20, 535-543. http://dx.doi.org/10.1016/S0263-7863(01)00054-0

Shiue, Y.C., \& Lin, C.Y. (2012). Applying analytic network process to evaluate the optimal recycling strategy in upstream of solar energy industry. Energy and Buildings, 54, 266-277. http://dx.doi.org/10.1016/j.enbuild.2012.07.032

Simpson, D., \& Samson, D.A. (2008). Developing strategies for green supply chain management. Decision Line, July, 12-15.

Srivastava, S. (2007). Green supply chain management-a state of the art literature review. International Journal of Management Review, 9(1), 53-80. http://dx.doi.org/10.1111/j.14682370.2007.00202.x

Stevels, A. (2002). Green supply chain management much more than questionnaires and ISO 14001. IEEE Conferences, 02, 96-100.

Toke, L.K., Gupta, R.C., \& Dandekar, M. (2010). Green supply chain management: Critical research and practices. Proceedings of the 2010 International Conference on Industrial Engineering and Operations Management Dhaka, Bangladesh, January 9-10, 2010.

Walker, H., Sisto, L.D., \& McBain, D. (2008). Drivers and barriers to environmental supply chain management practices: Lessons from the public and private sectors. Journal of Purchasing \& Supply Management, 14(1) 69-85. http://dx.doi.org/10.1016/j.pursup.2008.01.007

Walton, S.V., Handfield, R.B., \& Melnyk, S.A. (1998). The green supply chain: Integrating suppliers into environmental management processes. The Journal of Supply Chain Management, 34(2), 2-11. 
Wang, H.F., \& Gupta, S.M. (2011). Green supply chain management-A product life cycle approach. McGraw-Hill Prof Med/Tech, 2011, 384 pages. ISBN: 0071626085.

Wu, G.C., \& Hang, S.Y. (2009). The study of knowledge transfer and green management performance in green supply chain management. African Journal of Business Management, $4(1), 44-48$.

Wu, J., Dunn, S., \& Forman, H. (2012). A study on green supply chain management practices among large global corporations. Journal of Supply Chain and Operations Management, 10(1), 182-194.

Wu, T., Jim Wu, Y.C., Chen, Y.J., \& Goh, M. (2013).Aligning Supply Chain Strategy with Corporate Environmental Strategy: A Contingency Approach. International Journal of Production Economics (In Press). http://dx.doi.org/10.1016/j.ijpe.2013.02.027

Yan, L. (2011). Research on the performance measurement of green supply chain management in China. International Journal of Sustainable Development, 4(3), 101-107

Yu, L.C., \& Hui H.Y. (2008). An empirical study on logistics services provider, intention to adopt green innovations. Journal of Technology, Management and Innovation, 3(1), 17-26. ISSN: 0718-2724.

Yu, L.C. (2007). Adoption of green supply in Taiwan logistic industry. Journal of management study, August, 90-98. http://dx.doi.org/10.4028/0-87849-430-8.90

Zhu, Q., \& Sarkis, J. (2004). Relationships between operational practices and performance among early adopters of green supply chain management practices in Chinese manufacturing enterprises. Operations Management, 22(3), 265-289. http://dx.doi.org/10.1016/j.jom.2004.01.005

Zhu, Q., \& Sarkis, J. (2006). An inter sectoral comparison of green supply chain management in China: Drivers and practices. Journal of Cleaner Production, 14, 71-74. http://dx.doi.org/10.1016/j.jclepro.2005.01.003

Zhu, Q., Sarkis, J. \& Geng, Y. (2005). Green supply chain management in China: pressures, practices and performance. International Journal of Operations and Production Management, 25 (5), 449-468. http://dx.doi.org/10.1108/01443570510593148

Zhu, Q., Sarkis, J. \& Lai, K.H. (2007a). Initiatives and outcomes of green supply chain management implementation by Chinese manufacturers. Journal of Environmental Management, 85(1), 179-189. http://dx.doi.org/10.1016/j.jenvman.2006.09.003

Zhu, Q., Sarkis, J. \& Lai, K.H. (2007b). Green supply management: Pressures, practices and performance within the Chinese automobile industry. Journal of Cleaner Production, 15(11), 1041-1052. http://dx.doi.org/10.1016/j.jclepro.2006.05.021 
Zhu, Q., Sarkis, J. \& Lai, K.H. (2008a). Green supply chain management implications for "closing the loop". Transport Research Part E, 44(1), 1-18. http://dx.doi.org/10.1016/j.tre.2006.06.003

Zhu, Q., Sarkis, J. \& Lai, K.H. (2008b). Confirmation of a measurement model for green supply chain management practices implementation. International Journal of Production Economics, 111(2), 261-273. http://dx.doi.org/10.1016/j.ijpe.2006.11.029

Zhu, Q., Sarkis, J., \& Lai, K.H. (2012a). Green supply chain management innovation diffusion and its relationship to organizational improvement: An ecological modernization perspective. Journal of Engineering Technology Management, 29(1), 168-185. http://dx.doi.org/10.1016/j.jengtecman.2011.09.012

Zhu, Q., Sarkis, J., \& Lai, K.H. (2012b). Examining the effects of green supply chain management practices and their mediations on performance improvements. International Journal of Production Research, 50(5), 1377-1394. http://dx.doi.org/10.1080/00207543.2011.571937

Journal of Industrial Engineering and Management, 2013 (www.jiem.org)

Article's contents are provided on a Attribution-Non Commercial 3.0 Creative commons license. Readers are allowed to copy, distribute and communicate article's contents, provided the author's and Journal of Industrial Engineering and Management's names are included. It must not be used for commercial purposes. To see the complete license contents, please visit http://creativecommons.org/licenses/by-nc/3.0/. 